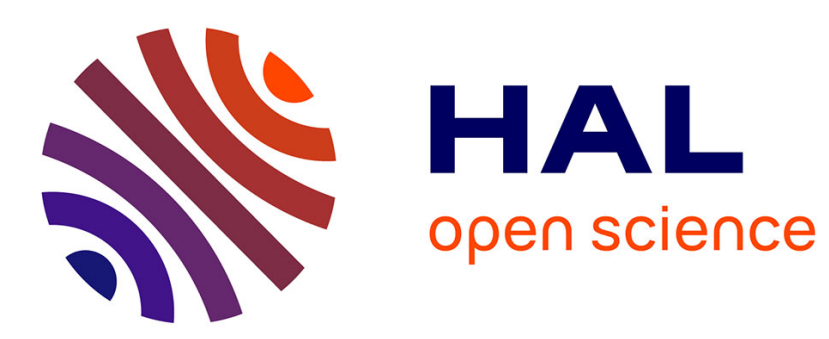

\title{
Molecular and biochemical analysis of Saccharomyces cerevisiae cox 1 mutants
}

\author{
C. Lemaire, S. Robineau, P. Netter
}

\section{To cite this version:}

C. Lemaire, S. Robineau, P. Netter. Molecular and biochemical analysis of Saccharomyces cerevisiae cox 1 mutants. Current Genetics, 1998, 34, pp.138-145. 10.1007/s002940050378 . cea-02474767

HAL Id: cea-02474767

https://hal-cea.archives-ouvertes.fr/cea-02474767

Submitted on 11 Feb 2020

HAL is a multi-disciplinary open access archive for the deposit and dissemination of scientific research documents, whether they are published or not. The documents may come from teaching and research institutions in France or abroad, or from public or private research centers.
L'archive ouverte pluridisciplinaire HAL, est destinée au dépôt et à la diffusion de documents scientifiques de niveau recherche, publiés ou non, émanant des établissements d'enseignement et de recherche français ou étrangers, des laboratoires publics ou privés. 


\section{Claire Lemaire $\cdot$ Sylviane Robineau $\cdot$ Pierre Netter \\ Molecular and biochemical analysis of Saccharomyces cerevisiae cox 1 mutants}

\begin{abstract}
We report on the molecular and biochemical analysis of a set of 13 respiratory deficient mutants of Saccharomyces cerevisiae which are specifically altered in COX1, the gene encoding the subunit Cox $1 \mathrm{p}$ of cytochrome $c$ oxidase. DNA sequence analysis shows that three are due to frameshift mutations, two to nonsense mutations, and eight to missense mutations. All, except the missense mutant S157L, have impaired electron transfer and respiratory activity. Analysis of the mitochondrial translation products shows that when Cox $1 p$ is absent, Cox $2 p$ and Cox3p are still synthesized. In the missense mutants, the steady state levels in the mitochondrial membranes of the three mitochondrially encoded subunits Cox $1 p, \operatorname{Cox} 2 p$ and Cox $3 p$ and the nuclear-encoded subunit Cox $4 p$ are reduced. In the frameshift and nonsense mutants, Cox $1 p$ is absent and Cox $2 p$, Cox $3 p$ and Cox $4 p$ are considerably decreased or undetectable. A comparison of the steady state levels of Cox $1 \mathrm{p}$ through Cox $4 \mathrm{p}$ in the COX1, COX2, COX3 and COX4 mutants shows the interdependance of the accumulation of these four subunits in the mitochondrial membranes.
\end{abstract}

Key words Cytochrome $c$ oxidase . Saccharomyces cerevisiae . Complex assembly

\section{Introduction}

Cytochrome $c$ oxidase, the terminal enzyme of the mitochondrial respiratory chain, catalyzes oxygen reduction

C. Lemaire $(\bowtie) \cdot S$. Robineau $\cdot$ P. Netter ${ }^{1}$

Centre de Génétique Moléculaire, Laboratoire propre du CNRS associé à l'Université Pierre et Marie Curie, F-91198 Gif-sur-Yvette cedex, France

e-mail: Lemaire@cgm.cnrs-gif.fr

Fax: +33-0-169075539

Present address:

${ }^{1}$ Institut Jacques Monod, 2 place Jussieu, Tour 43,

F-75251 Paris cedex 05, France

Communicated by K. Wolf and connects this reaction to the generation of a proton gradient across the inner mitochondrial membrane. Recently, two different three-dimensional structures of heme copper oxidases have been reported almost simultaneously: the bacterial cytochrome aa 3 of Paracoccus denitrificans which consists of four subunits (Iwata et al. 1995) and the eucaryotic cytochrome aa3 of beef heart mitochondria which contains 13 subunits (Tsukihara et al. 1995, 1996). These structures present the detailed organization of the metal centers. In the case of the beef heart enzyme, involvement of some amino acids in proton-, water- and bimolecular oxygen-channels has been discussed (Tsukihara et al. 1996). In P. denitrificans, the structure has led the authors to propose a mechanism of proton pumping that can be tested by site-directed mutagenesis (Iwata et al. 1995).

In eucaryotes, the possibility of isolating mutants is limited and is more laborious than in bacteria. However, the facultative aerobe Saccharomyces cerevisiae is a powerful tool for isolating respiratory deficient mutants which would be lethal in strictly aerobic eucaryotes. In S. cerevisiae, cytochrome $c$ oxidase consists of 11 subunits (Geier et al. 1995). Cox $1 p$, Cox $2 p$ and Cox3p are encoded in the mitochondrial DNA (Rubin and Tzagoloff 1973) while the other subunits are of nuclear origin (for review, see Poyton and McEwen 1996). The gene coding for Cox $1 \mathrm{p}$ is split and contains eight exons (A1 to A8) and seven introns (aI1 to aI7) (Bonitz et al. 1980; Hensgens et al. 1983). S. cerevisiae Cox $1 \mathrm{p}$ is $50 \%$ identical (and 69\% similar) to that of P. denitrificans, and 58\% identical (and 77\% similar) to that of beef heart mitochondria. Studies of missense mutants of $S$. cerevisiae could be useful in elucidating the reaction mechanism of the cytochrome $c$ oxidase complex. On the other hand, analysis of cytochrome $c$ oxidase subunits in strains carrying nonsense mutations may give information on the mode of assembly of the complex (for a review see Capaldi 1990).

In the present study, we report the molecular and biochemical characteristics of a set of exonic coxl mutants in S. cerevisiae which have lost their ability to grow on respiratory substrates. The accumulation of Cox $1 p$ to Cox $4 p$ in the mitochondrial membranes of the coxl mutants com- 
Table 1 List of strains

\begin{tabular}{|c|c|c|c|}
\hline Name & Nuclear genotype & $\begin{array}{l}\text { Mitochondrial } \\
\text { genotype }\end{array}$ & Origin \\
\hline $777-3 \mathrm{~A}$ & MAT $\alpha$ adel opl & $\mathrm{rho}^{+} \mathrm{mit}^{+}$ & Kotylak and Slonimski (1977) \\
\hline $\begin{array}{l}\text { 777-3A/G291 to G2394 } \\
777-3 \mathrm{~A} / \mathrm{V} 44-\mathrm{V} 206\end{array}$ & MAT $\alpha$ ade1 opl & $\mathrm{rho}^{+} \mathrm{mit}^{-}$ & Kotylak and Slonimski (1977) \\
\hline BGT1 & $\begin{array}{l}\text { MATa ade } 2 \text { ura3-1 trpl-1 } \\
\text { his3-11,15 leu2-3,112 } \\
\text { can1-100 COXIV::TRP1 }\end{array}$ & $\mathrm{rho}^{+} \mathrm{mit}^{+}$ & Kindly provided by B. Guiard \\
\hline KM612-2D & MAT $\alpha$ ade $1 O P$ & rho $^{+}$mit $^{-}$ & Dujardin (1983) \\
\hline KM612-2D/60 & MAT $\alpha$ adel OP & $r h o^{\circ}$ & $\begin{array}{l}\text { Ethidium bromide mutagenesis } \\
\text { of KM612-2D (this work) }\end{array}$ \\
\hline KL14-4A/60 & MATa hisl trp2 OP & $r h o^{\circ}$ & Groudinsky et al. (1981) \\
\hline
\end{tabular}

pared to $\operatorname{cox} 2, \operatorname{cox} 3$ and $\operatorname{cox} 4$ mutants provides some insight into the stability of these subunits in these various cytochrome $c$ oxidase-defective mutants.

\section{Materials and methods}

Strains and media. All the strains are listed in Table 1. The mit ${ }^{-}$mutants were isolated from the haploid strain 777-3A (opl), mapped to the $C O X 1, C O X 2$ or $C O X 3$ genes (Kotylak and Slonimski 1977) and were localized more precisely, for the coxl mutants, by deletion mapping (Netter et al. 1982, 1995). The cox2 mutant (V44) and the cox3 mutant (V206) have been previously described as defective in the synthesis of Cox2p and Cox3p respectively (Kruszewska et al. 1980; Baranowska et al. 1983). Growth analyses were performed on diploid strains constructed by crossing the various mutants with the strain KL14-4A/60. All the other experiments have been performed on haploid strains. The media N3, NE and NL were as described in Dujardin et al. (1980). YPGAL medium contained 2\% galactose, $1 \%$ bactopeptone and $1 \%$ yeast extract. YPGALa was the same as YPGAL but with the addition of $2 \mu \mathrm{g} / \mathrm{ml}$ of adenine.

Sequence analysis of the coxl mutations. For analysis of the mutations G1099, G1547 and G2508, single-stranded DNA was sequenced according to Sanger et al. (1977) after cloning into M13/ mp18 or M13/mp19. To identify mutations G2567, G291, G450, W164, G1979, G2394 and G2276, double-stranded PCR products were cloned into pBluescript KS+ (Stratagene) and two clones per mutation were sequenced.

Pulse-labelling experiments and preparation of mitochondrial membranes. Pulse-labelling experiments were carried out according to Claisse et al. (1980) except that cells were re-suspended in $0.4 \mathrm{M}$ mannitol, $50 \mathrm{mM}$ Tris/ $\mathrm{H}_{2} \mathrm{SO}_{4} \mathrm{pH} 7.4,2 \mathrm{mM}$ EDTA, $1 \mathrm{mM}$ phenyl methyl sulfonyl fluoride, $10 \mu \mathrm{g} / \mathrm{ml}$ leupeptin, $10 \mu \mathrm{g} / \mathrm{ml}$ antipaïn, $10 \mu \mathrm{g} / \mathrm{ml}$ chymostatin and $1 \mu \mathrm{g} / \mathrm{ml}$ pepstatin. Mitochondrial membranes were then prepared according to LaMarche et al. (1992). Protein concentrations were determined using Bio-Rad protein assay.

SDS-polyacrylamide gel electrophoresis. Electrophoresis was performed using the Laemmli system (Laemmli 1970). The molecular weights of the polypeptides were estimated using a low-molecularweight calibration kit from Bio-Rad.

Immunoblots experiments. Electrophoretic transfers were carried out according to Towbin et al. (1979). Immunodetection was carried out using an enhanced chemiluminescence (ECL) method according to the manufacturer's instructions (Amersham International). The monoclonal antibodies anti-yeast cytochrome $c$ oxidase Cox1p, Cox $2 p$, Cox $3 p$ and Cox $4 p$ were purchased from Molecular Probes and have been described in Taanman and Capaldi (1993). The poly- clonal antibody anti-yeast cytochrome $c$ oxidase Cox6p was kindly provided by R. O. Poyton.

Activity and cytochrome spectra measurements. Oxygen consumption was measured with a Clark electrode (Gilson oxygraph), at $28^{\circ} \mathrm{C}$, using $2 \%$ ethanol as the substrate. The effect of the uncoupler was tested by the addition of $25 \mu \mathrm{M}$ of Carbonyl-cyanide-p-trichlorophenylhydrazone and cyanide-sensitive respiration was measured in the presence of $0.5 \mathrm{mM} \mathrm{KCN}$. Respiratory rates were expressed in nmoles $\mathrm{O}_{2}$ consumed $/ \mathrm{min}$ per $5 \times 10^{8}$ cells, taking into account that the solubility of $\mathrm{O}_{2}$ is $243.75 \mu$ moles $/ 1$ of $\mathrm{H}_{2} \mathrm{O}$ at $28^{\circ} \mathrm{C}$. Cytochrome $c$ oxidation measurements were performed spectrophotometrically as described in Pajot et al. (1976). Cytochrome absorption spectra were recorded on whole-cell pastes at liquid nitrogen temperature, after dithionite reduction, according to Claisse et al. (1970).

\section{Results}

\section{Sequences of the coxl mutations}

The mutations had been previously localized by deletion mapping in the mitochondrial COX1 gene (Netter et al. 1982, 1995). Sequencing revealed that the mutations are in positions consistent with their location determined by deletion mapping. All the results are listed in Table 2. Amongst the 13 mutants studied, two display a nonsense mutation: G2508 (S219ochre) and G291 (Y245ochre), and three a frameshift mutation: G1099 (N99ochre), G2567 (L109amber) and G1547 (L212amber), leading to a nonsense mutation downstream (see Table 3). Eight exhibit a single missense mutation, except for G2394 which is a double mutant in which the second mutation is silent $(\mathrm{C} 12583 \mathrm{~T} \rightarrow \mathrm{Y} 394 \mathrm{Y})$. The six missense mutations are located mainly in exons A4 and A5, while G1979 (G330D) and G2394 (G384D) are localized in exons A6 and A8 respectively. The implications of the amino-acid changes will be considered in the Discussion section.

\section{Respiratory growth and activities of the coxl mutants}

All the mutants have been previously selected for their inability to grow on glycerol medium (N3) (Kotylak and Slonimski 1977). We completed this analysis by testing the 
Table 2 Nature and localization of the COXI mutations and analysis of COX1 mRNA synthesis. The nucleotides are numbered from 1 to 13003 , starting at position -126 of the short strain (Bonitz et al. 1980) and interrupted for exons A5 to A7 by 3060 nucleotides of the long strain (Hensgens et al. 1983)

\begin{tabular}{|c|c|c|c|c|c|c|}
\hline Mutant & Mutation & $\begin{array}{l}\text { Nucleotide } \\
\text { change }\end{array}$ & $\begin{array}{l}\text { Exon } \\
\text { localization }\end{array}$ & $\begin{array}{l}\text { Amino-acid } \\
\text { change }\end{array}$ & $\begin{array}{l}\text { Amino-acid } \\
\text { conservation }^{b}\end{array}$ & $\begin{array}{l}\text { COX1 mRNA } \\
\text { synthesis }\end{array}$ \\
\hline 777-3A/G1099 & Frameshift & T6896TT & A4 & See Table 3 & na & + \\
\hline 777-3A/G1547 & Frameshift & G7219d & A4 & See Table 3 & na & + \\
\hline 777-3A/G2508 & Nonsense & C7259A & A4 & S219ochre & na & + \\
\hline 777-3A/G291 & Nonsense & T8348A & A5 & Y245ochre & na & nd \\
\hline $777-3 \mathrm{~A} / \mathrm{G} 2276$ & Missense & $\mathrm{C} 7073 \mathrm{~T}$ & A4 & S157L & Conserved (29/31) & + \\
\hline 777-3A/G450 & Missense & G8340A & A5 & E243K & Invariant $(31 / 31)$ & + \\
\hline $777-3 \mathrm{~A} / \mathrm{G} 3015^{\mathrm{a}}$ & Missense & G8343A & A5 & V244M & Invariant $(31 / 31)$ & + \\
\hline $777-3 \mathrm{~A} / \mathrm{W} 113^{\mathrm{a}}$ & Missense & G8364A & A5 & G251R & Conserved $(22 / 31)$ & + \\
\hline 777-3A/W201 ${ }^{\mathrm{a}}$ & Missense & A8407T & A5 & $\mathrm{K} 265 \mathrm{M}$ & Conserved $(27 / 31)$ & nd \\
\hline 777-3A/W164 & Missense & $\mathrm{C} 8481 \mathrm{~T}$ & A5 & H290Y & Invariant $(31 / 31)$ & + \\
\hline 777-3A/G1979 & Missense & G9967A & A6 & G330D & Conserved $(24 / 31)$ & + \\
\hline 777-3A/G2394 & Missense & $\mathrm{G} 12552 \mathrm{~A}+\mathrm{C} 12583 \mathrm{~T}$ & A8 & G384D+Y394Y & Conserved (29/31) & + \\
\hline
\end{tabular}

na $=$ not applicable; nd $=$ not done; $\Delta$ : deletion

a Sequenced by Lemarre et al. (1994)

b The amino-acid conservation has been considered in terms of the alignment of 31 sequences of Cox $1 \mathrm{p}$ including bacteria, fungi, plants and animals

Table 3 Localization of the frameshift mutations and positions of the nonsense codons generated

\begin{tabular}{|c|c|c|c|c|c|c|c|c|c|}
\hline Strain & Sequence & & & & & & & & \\
\hline $777-3 \mathrm{~A}$ & $\begin{array}{l}\text { WT nucleotide sequence } \\
\text { Nucleotide position } \\
\text { WT amino-acid sequence } \\
\text { Amino-acid position }\end{array}$ & $\begin{array}{l}\text { ATT } \\
6894 \\
\text { I } \\
98\end{array}$ & $\begin{array}{l}\text { AAT } \\
\text { N } \\
99\end{array}$ & & & & & & \\
\hline 777-3A/G1979 & $\begin{array}{l}\text { Mutant nucleotide sequence } \\
\text { Mutant amino-acid sequence }\end{array}$ & $\begin{array}{l}\text { ATT } \\
\text { I }\end{array}$ & $\begin{array}{l}\text { TAA } \\
\text { ochre }\end{array}$ & & & & & & \\
\hline $777-3 \mathrm{~A}$ & $\begin{array}{l}\text { WT nucleotide sequence } \\
\text { Nucleotide position } \\
\text { WT amino-acid sequence } \\
\text { Amino-acid position }\end{array}$ & $\begin{array}{l}\text { TTT } \\
6910 \\
\text { F } \\
102\end{array}$ & $\begin{array}{l}\text { TGA } \\
\mathrm{W}\end{array}$ & $\begin{array}{l}\text { GTA } \\
\mathrm{V}\end{array}$ & $\begin{array}{l}\text { TTA } \\
\text { L }\end{array}$ & $\begin{array}{l}\mathrm{CCT} \\
\mathrm{P}\end{array}$ & $\begin{array}{l}\text { ATG } \\
\text { M }\end{array}$ & $\begin{array}{l}\text { GGG } \\
\text { G }\end{array}$ & $\begin{array}{l}\text { TTA } \\
\text { L } \\
109\end{array}$ \\
\hline 777-3A/G2567 & $\begin{array}{l}\text { Mutant nucleotide sequence } \\
\text { Mutant amino-acid sequence }\end{array}$ & $\begin{array}{l}\text { TTT } \\
\text { F }\end{array}$ & $\begin{array}{l}\text { GAG } \\
\text { E }\end{array}$ & $\begin{array}{l}\text { TAT } \\
\text { Y }\end{array}$ & $\begin{array}{l}\text { TAC } \\
\text { Y }\end{array}$ & $\begin{array}{l}\text { CTA } \\
\text { T }\end{array}$ & $\begin{array}{l}\text { TGG } \\
\text { W }\end{array}$ & $\begin{array}{l}\text { GGT } \\
\text { G }\end{array}$ & $\begin{array}{l}\text { TAG } \\
\text { amber }\end{array}$ \\
\hline $777-3 \mathrm{~A}$ & $\begin{array}{l}\text { WT nucleotide sequence } \\
\text { Nucleotide position } \\
\text { WT amino-acid sequence } \\
\text { Amino acid position }\end{array}$ & $\begin{array}{l}\text { GGT } \\
7219 \\
\text { G } \\
206\end{array}$ & $\begin{array}{l}\text { ATT } \\
\text { I }\end{array}$ & $\begin{array}{l}\text { ACA } \\
\mathrm{T}\end{array}$ & $\begin{array}{l}\text { ATG } \\
\text { M }\end{array}$ & $\begin{array}{l}\text { TTA } \\
\text { L }\end{array}$ & $\begin{array}{l}\text { TTA } \\
\text { L }\end{array}$ & $\begin{array}{l}\text { TTA } \\
\text { L } \\
212\end{array}$ & \\
\hline 777-3A/G1547 & $\begin{array}{l}\text { Mutant nucleotide sequence } \\
\text { Mutant amino-acid sequence }\end{array}$ & $\begin{array}{l}\text { GTA } \\
\text { V }\end{array}$ & $\begin{array}{l}\text { TTA } \\
\text { L }\end{array}$ & $\begin{array}{l}\text { CAA } \\
Q\end{array}$ & $\begin{array}{l}\text { TGT } \\
\text { C }\end{array}$ & $\begin{array}{l}\text { TAT } \\
\text { Y }\end{array}$ & $\begin{array}{l}\text { TAT } \\
\text { Y }\end{array}$ & $\begin{array}{l}\text { TAG } \\
\text { amber }\end{array}$ & \\
\hline
\end{tabular}

thermosensitivity or cryosensitivity of these strains and their growth on other non-fermentable media. Strains carrying the various mitochondrial mutations were incubated on $\mathrm{N} 3$ medium at different temperatures, $20^{\circ} \mathrm{C}, 28^{\circ} \mathrm{C}$ and $36^{\circ} \mathrm{C}$, and were tested on NL (lactate) and NE (ethanol) media at $28^{\circ} \mathrm{C}$. After 3 days of incubation, no growth was observed under any condition. Extending the time of incubation leads to the appearance of rare revertants.

As has been previously shown for the cytochrome $b c 1$ complex (Oudshoorn et al. 1987; Tron and Lemesle-Meunier 1990), there is no direct relationship between growth on non-fermentable media of a strain altered in a given complex and the activity of this complex. Thus, measurements of the respiratory activity of the different coxl mu- tants were made in vivo by following the rate of $\mathrm{O}_{2}$ consumption in intact cells. In all but one of the cox 1 mutants tested, the rate of oxygen uptake is not significantly different from a $r h o^{\circ}$ strain lacking mitochondrial DNA (KM612-2D/60) or a mit $^{-}$strain with a mutation located in the intron aI2, which leads to a lack of COX1 mRNA (W165) (Carignani et al. 1986). Surprisingly, even though it does not grow on non-fermentable media, the mutant S157L displays a residual respiratory activity of 38 nmoles $\mathrm{O}_{2}$ consumed $/ \mathrm{min} / 5 \times 10^{8}$ cells (about $15 \%$ compared to the wild-type (wt) strain). This activity is cyanide-sensitive.

Activity measurements were also performed in vitro, estimating the efficiency of the electron transfer chain by the ability of purified mitochondrial membranes to oxidize 


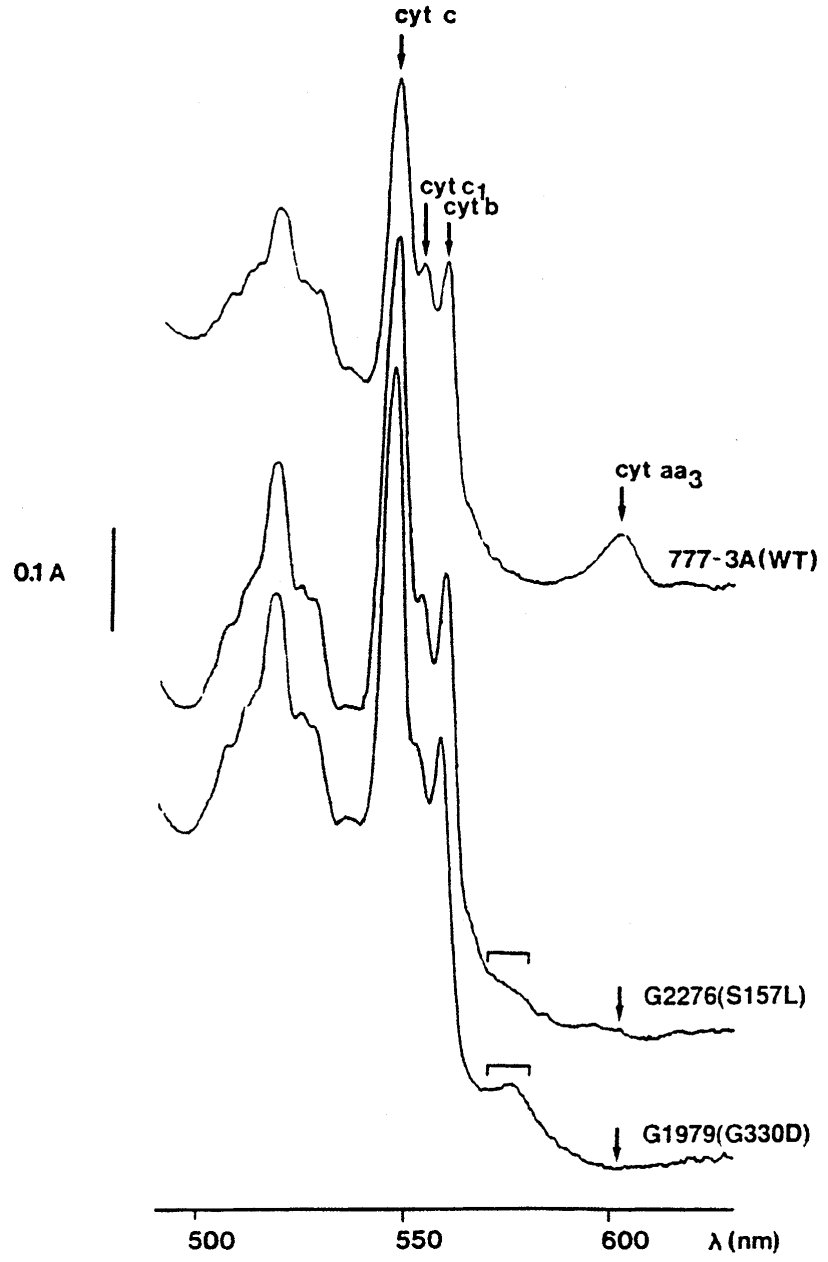

Fig. 1 Cytochrome spectra of whole cells from the wt strain 7773A, mutants G1979 (G330D) and G2276 (S157L). Cells were grown for 2 days at $28^{\circ} \mathrm{C}$ on solid YPGALa medium. Spectra were performed at $-180^{\circ} \mathrm{C}$ on dithionite-reduced whole-cell pastes (1-mm thick). In G1979 (G330D) and G2276 (S157L), the square bracket indicates the presence of a shoulder between 570 and $580 \mathrm{~nm}$

an exogenous electron donor, cytochrome $c$. The initial rate of the cyanide-sensitive cytochrome $c$ oxidation of the wt strain is 650 nmoles of oxidized cytochrome $c /$ min per $\mathrm{mg}$ of protein. For the coxl mutants, the activities are not significatively different from the negative control (W165) except for the strain S157L which displays an activity of about $20 \%$ of that observed in wt and which is also cyanide-sensitive.

\section{Cytochrome spectra of coxl mutants}

Cytochrome spectra of the wt strain and mutants G330D (representative of the mutants lacking of any respiratory activity) and S157L are shown in Fig. 1. As expected, the wt strain presents a significant peak at $602 \mathrm{~nm}$ corresponding to the $\alpha$ band of cytochromes $a$ and $a 3$. S157L shows a slight shoulder at this position and its cytochrome aa3/ cytochrome $c$ ratio is estimated to be about $7 \%$ of wt. In

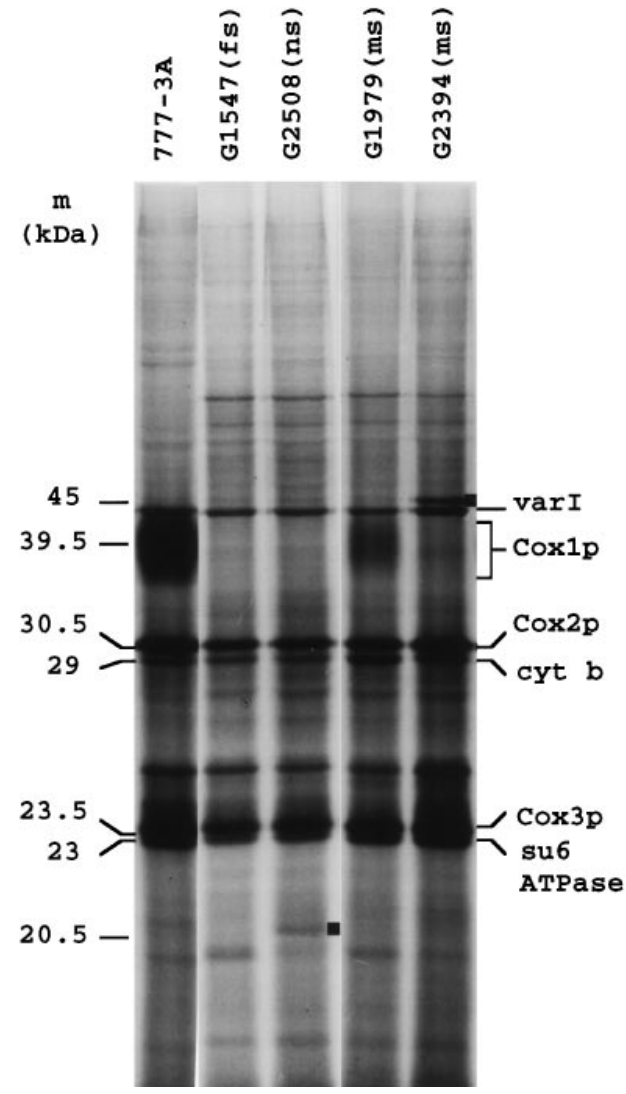

Fig. 2 Autoradiograms of mitochondrial translation products. Cells were pulse-labelled for $60 \mathrm{~min}$ with ${ }^{35} \mathrm{SO}_{4}$ in the presence of cycloheximide and mitochondrial membranes were purified and analyzed by an SDS polyacrylamide gel as described in the Materials and methods. FS frameshift; $N S$ nonsense; $M S$ missense. G1547 is representative of all the frameshift and nonsense mutants except G2508, while G1979 (G330D) is representative of all the missense mutants except G2394 (G384D). Note the presence of novel polypeptides (indicated by $\mathbf{m})$ in the strains G2508 and G2394 (G384D)

G330D, as in the 11 other mutants, no cytochromes aa3 can be detected. In all mutants, the cytochrome $b /$ cytochrome $c$ ratio and the cytochrome $c 1 /$ cytochrome $c$ ratio are decreased (by about 20-40\%) indicating a deficiency in the accumulation of cytochromes $b c l$. Such a decrease in all the cytochromes has already been reported (Lemesle-Meunier et al. 1993).

Analysis of the translation products in the coxl mutants

Since all the tested exonic coxl mutants displayed a significant level of coxl mRNA (data not shown), we examined whether the respiratory deficiency of the mutants was due to an alteration either at the translational or at the posttranslational level. The mitochondrial translation products are shown in Fig. 2. The band corresponding to Cox $1 p$ $(39.5 \mathrm{kDa})$ was lacking in the frameshift and nonsense mutants (represented by G1547), as well as in the missense mutant G384D, and was present, but reduced, in the other missense mutants (represented by G330D). In two mutants 


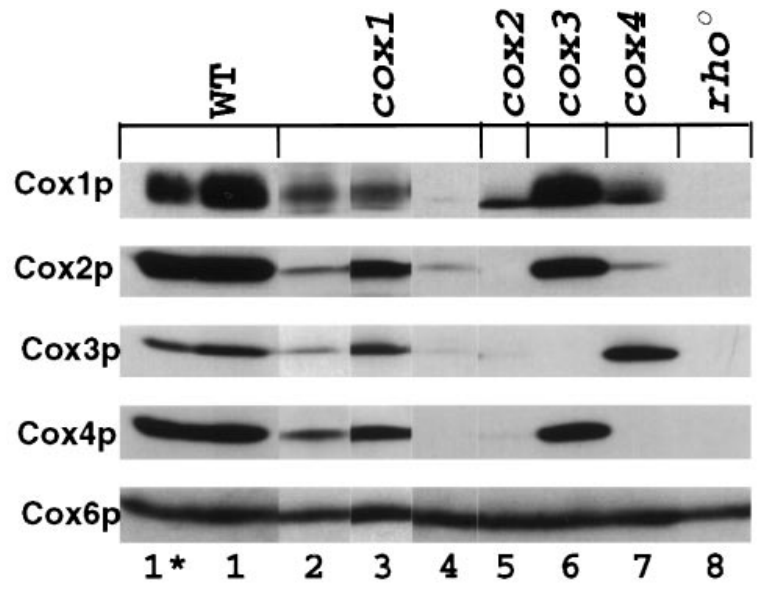

Fig. 3 Immunoblots of mitochondrial membranes from the wt strain, $\operatorname{cox} 1, \operatorname{cox} 2, \operatorname{cox} 3$ and $\operatorname{cox} 4$ mutants and the rho strain. The loading corresponds to $40 \mu \mathrm{g}$ of mitochondrial membranes except when specified by * which corresponds to $20 \mu \mathrm{g}$ of mitochondrial membranes. Lanes 1 and $1^{*}$ WT strain, 777-3A. Lane 2 G1979 (G330D), coxl missense mutant defective in cytochrome $c$ oxidase activity. Lane 3 G2276 (S157L), coxl missense mutant displaying $20 \%$ of cytochrome $c$ oxidase activity. Lane $4 \mathrm{G} 1547$, frameshift cox1 mutant. Lane 5 V44, cox2 mutant. Lane $6 \mathrm{~V} 206$, cox3 mutant. Lane $7 \mathrm{BGT} 1$, cox 4 mutant. Lane $8 \mathrm{rho}^{\circ}$ strain

devoid of Cox $1 \mathrm{p}$, novel polypeptides were observed: in G384D we noted the presence of a $45-\mathrm{kDa}$ polypeptide, which is not recognized by the monoclonal Cox $1 \mathrm{p}$ antibody we used (data not shown), and in G2508 the additional polypeptide displays an apparent molecular weight of $20.5 \mathrm{kDa}$ which is compatible with the predicted truncated polypeptide. In all the mutants, Cox $2 p$ and Cox $3 p$, corresponding respectively to the $30.5-\mathrm{kDa}$ and $23.5-\mathrm{kDa}$ polypeptides, were synthesized.

\section{Immunoblotting experiments with cox mutants}

Using immunoblotting, we examined the stability of Cox $1 p, \operatorname{Cox} 2 p$ and Cox $3 p$ and of the nuclear-encoded Cox4p, all of which are closely associated (Tsukihara et al. 1996), in the presence of mutations in each of the corresponding genes (coxl, $\operatorname{cox} 2, \operatorname{cox} 3$ or $\operatorname{cox} 4$ mutants). The same analysis was also performed on a $r h o^{\circ}$ strain which lacks all three mitochondrial subunits. As a control, the stability of the nuclear-encoded Cox6p, which has no direct contact with Cox $1 \mathrm{p}$ through Cox $4 \mathrm{p}$ (Tsukihara et al. 1996), was also determined.

In the missense coxl mutants, the levels of the three mitochondrially encoded subunits and of Cox $4 p$ are reduced. This is illustrated in Fig. 3 with the mutant G330D (lane 2), which is devoid of any cytochrome $c$ oxidase activity, and the mutant S157L (lane 3), which displays a residual cytochrome $c$ oxidase activity of about $20 \%$. In the frameshift and nonsense coxl mutants (represented by G1547, lane 4), Cox 1p is absent and the levels of Cox $2 p$, Cox3p and Cox $4 p$ are considerably decreased or else undetectable. In the cox2 mutant (V44, lane 5) Cox1p is present in small amounts and Cox $3 p$ and Cox $4 p$ are barely detectable, whereas in the cox3 mutant (V206, lane 6) significant amounts of Cox $1 p$ and Cox $2 p$ are observed and Cox $4 p$ accumulates to the wt level. In the absence of Cox $4 p$ (BGT1, lane 7) the levels of Cox1p and Cox $2 p$ are low, whereas Cox3p is even higher than in the wt strain. In the absence of the three mitochondrially encoded subunits (rho ${ }^{\circ}$ strain, lane 8) Cox $4 \mathrm{p}$ is absent. In all the mutants studied Cox6p accumulates as well as in the wt.

\section{Discussion}

Analysis of the amino-acid substitutions in the missense mutants

The analysis of the missense mutants reveals that, with the exception of S157L, the substitution of one amino acid has a drastic effect abolishing any accumulation of the cytochromes $a$ and $a 3$ and any cytochrome $c$ oxidase activity. These observations are correlated with a decrease in Cox $1 p$ translation and in the level of Cox $1 p, \operatorname{Cox} 2 p, \operatorname{Cox} 3 p$ and Cox $4 p$ accumulated in the membranes. All these observations led us to conclude that these mutants are altered in the assembly of the cytochrome $c$ oxidase complex as a consequence of the instability of Cox 1p. According to the crystal structure of bovine heart cytochrome $c$ oxidase (Tsukihara et al. 1996) (see Fig. 4), five of the missense mutations are located in the trans-membrane helices: helix 4 (S157L), helix 6 (V244 M, E243 K and G251R) and helix $10(\mathrm{G} 384 \mathrm{D})$. Three mutations are in extra-membrane regions: K265 M and G330D in regions H6-7 and H8-9 respectively, orientated towards to the matrix side of the inner mitochondrial membrane, and H290Y in the H7-8 region on the periplasmic side.

Four mutations affect positions which are essential in the published structures (Iwata et al. 1995; Tsukihara et al. $1995,1996)$. Our results are in good agreement with these data. The mutation $\mathrm{H} 290 \mathrm{Y}$ alters an invariant histidine residue which is proposed to be one of the $\mathrm{CuB}$ ligands (Iwata et al. 1995; Tsukihara et al. 1995). In addition, Iwata et al. (1995) suggest that this residue could be involved in a histidine cycle/shuttle mechanism for the coupling of proton pumping to oxygen reduction. Three mutants (E243K, S157L and K265M) are altered in the positions of invariant or conserved amino acids (see Table 2) which have been proposed to be involved in proton channels either in the pathway for consumed protons (E243 and K265) (Iwata et al. 1995) or in the pathway for pumped protons (S157) (Tsukihara et al. 1996). S157L carries the only missense mutation, which led to a partial accumulation of an active complex in the mitochondrial membranes.

The three other mutants, G330D, G384D and G251R, do not affect invariant residues. However, we show here that they have important roles since they alter the level of Cox $1 p$, Cox $2 p$, Cox $3 p$ and Cox $4 p$ accumulated in the membranes and lead to an absence of detectable cytochrome $c$ oxidase activity. All of them change a glycine residue. A 
Fig. 4 Two-dimensional organization of the cytochrome $c$ oxidase subunit I of $S$. cerevisiae. The distribution of the trans-membrane helices and of the two helices parallel to the membrane has been deduced from the structure of subunit I of cytochrome oxidase from beef heart (Tsukihara et al. 1996) and after alignment of its sequence with that of $S$. cerevisiae. Rectangles in the N-terminal and H9-10 regions are $\alpha$ helices found in the extra-membrane region. The localization of the eight missense mutations and the amino-acid changes observed in these mutants are indicated. The extra-membrane regions are numbered from H1-2 to H11-12, and the transmembrane helices from TM1 to TM12 according to the nomenclature of Iwata et al. (1995)

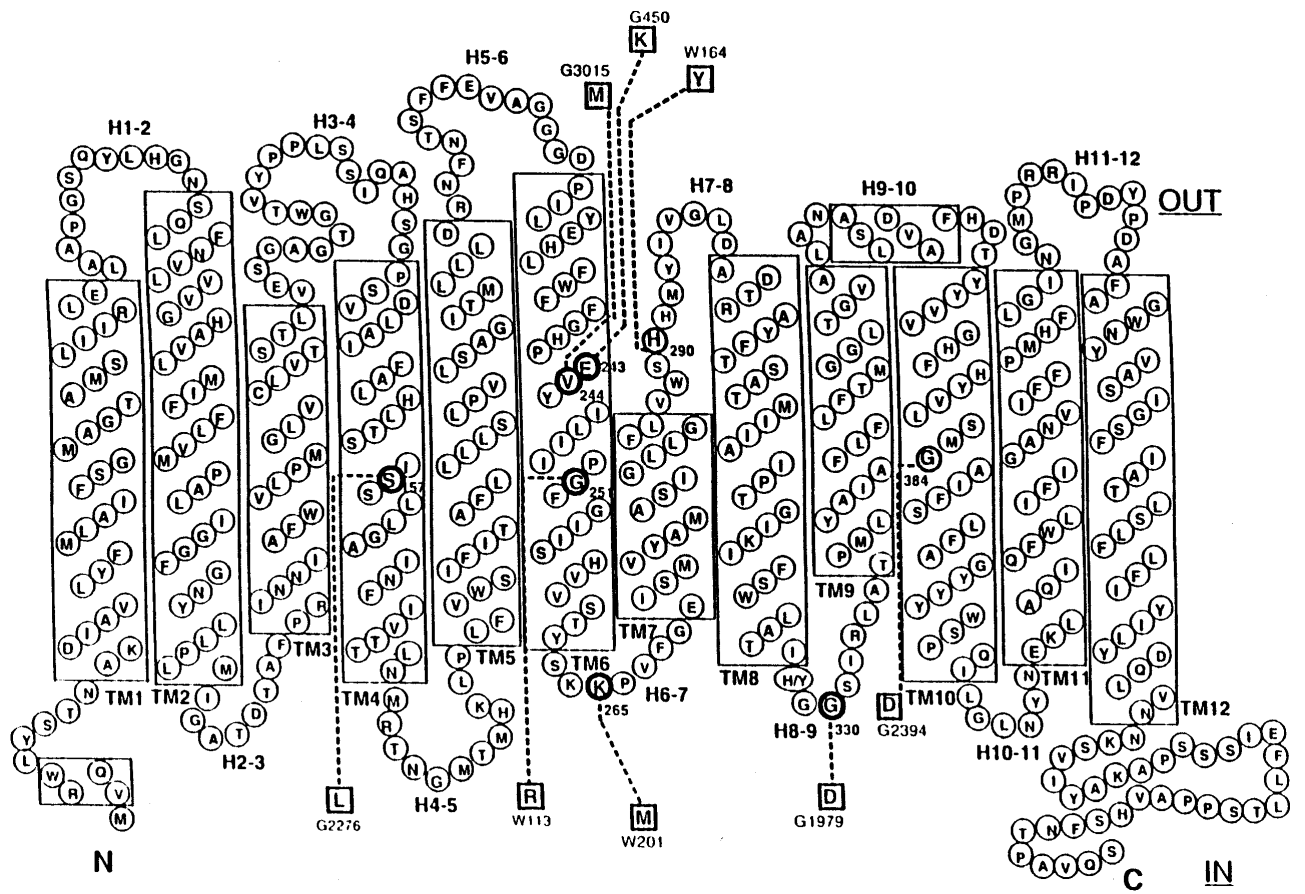

similar substitution (G352 V) has been studied by Ortwein et al. (1997) but this resulted in a well-assembled but nonfunctional cytochrome $c$ oxidase complex. In our case, the three amino-acid substitutions result in the appearance of a charge either in a trans-membrane region (TM6 for G251R and TM10 for G384D) or in a loop orientated to the matrix (H8-9 for G330D) (see Fig. 4). Consequently, we hypothesize that it is the presence of the charge which induces a change in the conformation of Cox $1 p$, thereby altering its stability in the membranes.

Analysis of the stability of Cox $1 p, \operatorname{Cox} 2 p, \operatorname{Cox} 3 p$, Cox $4 p$ and Cox6p in the mitochondrial membranes of mutants lacking one subunit

The comparison of the subunit content in the various mutants lacking either Cox $1 p, \operatorname{Cox} 2 p, \operatorname{Cox} 3 p$ or Cox $4 p$ shows that $\operatorname{Cox} 1 p, \operatorname{Cox} 2 p, \operatorname{Cox} 3 p$ and $\operatorname{Cox} 4 p$ accumulate in an inter-dependant way, whereas the accumulation of Cox6p appears to be independant from the four others. Indeed, Cox $4 p$ is not detectable in the rho ${ }^{\circ}$ strain while Cox $6 p$ accumulates as well as in the wt cells. Cox $4 p$ is also absent in $\operatorname{cox} 1$ and $\operatorname{cox} 2$ mutants, but not in $\operatorname{cox} 3$ mutants. Thus, the accumulation of Cox $4 p$ in the membranes appears to be dependent on the presence of Cox $1 p$ and Cox $2 p$. By contrast, in all the mutants studied, Cox6 accumulates as well as in the wt strain. Similar observations have been made by Taanman et al. (1996) in the human cell line 143B206 (which is devoid of mitochondrial DNA), where the human homolog for Cox $4 \mathrm{p}$ is reduced while the homo$\log$ for Cox $6 \mathrm{p}$ is present in amounts close to the mtDNAcontaining parental cell line. Recently, Glerum and Tzagoloff (1997) have reported that Cox4p is accumulated in

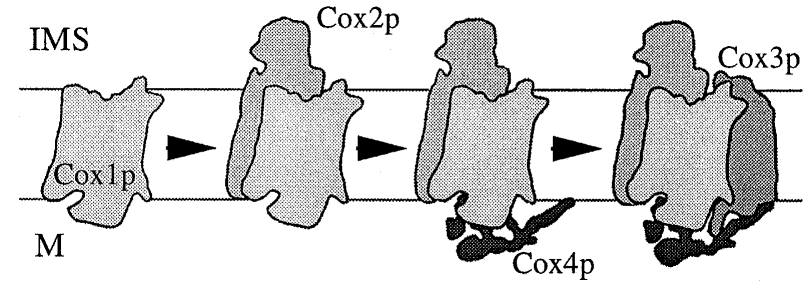

Fig. 5 Hypothetical model for the sequential assembly of the three mitochondrially encoded subunits (Cox $1 p$, Cox $2 p$ and Cox $3 p$ ) and the nuclear-encoded subunit (Cox4p) of cytochrome $c$ oxidase into the mitochondrial membranes. IMS inter-membrane space; $M$ matrix

comparable amounts in a nuclear mutant altered in the maturation/stability of $C O X 1 \mathrm{mRNA}$ and in wt mitochondria, but in the mutant the protein is recovered almost entirely in the soluble fraction.

Taken together, these results confirm the interdependance of the assembly of Cox $4 p$ and Cox $1 p$ in the membranes. The difference in the accumulation of the two nuclearly encoded subunits Cox $4 p$ and Cox6 could be due to a distinct assembly pathway. This is supported by the crystallographic data (Tsukihara et al. 1997) showing that Cox $4 p$ and Cox $6 p$ are both extra-membrane subunits, but whereas Cox $4 p$ tightly interacts with Cox $1 p$ and Cox $3 p$, Cox6p is without any direct contact with Cox $1 p$.

Mitochondrial proteins of the inner membrane in yeast are rapidly degraded when not assembled. In particular, this has been shown by Nakai et al. (1994) for Cox $2 p$ and Cox $3 p$ which were degraded rapidly in a mutant lacking Cox $4 p$. Several mitochondrial proteases have been identified like the hetero-oligomeric $\mathrm{Afg} 3 \mathrm{p} / \mathrm{Rca} 1 \mathrm{p}$ complex which degrade Cox $1 p$ and Cox $3 p$, or Yme1p which is involved in the degradation of Cox $2 p$ (for review see Langer 
and Neupert 1996; Suzuki et al. 1997). However, Glerum and Tzagoloff (1997) have shown that in a cox6 background, the steady state amount of Cox $1 \mathrm{p}$ is not regulated by Afg $3 p / R c a 1 p$ and these authors have suggested that other proteases could exist. It would be interesting to determine which protease(s) is (are) involved in the subunit degradation in our cytochrome $c$ oxidase mutants.

In conclusion, the deleterious effect produced by the absence of Cox $1 p$ on Cox $2 p, \operatorname{Cox} 3 p$ and Cox $4 p$ suggests that Cox $1 p$ is necessary for the assembly of these subunits. In the cox 2 mutant, Cox $3 p$ and Cox $4 p$ were also absent indicating that their accumulation requires the presence of Cox $2 p$. In the cox3 mutant, Cox $1 p$, Cox $2 p$ and Cox $4 \mathrm{p}$ accumulate in a significant way and a slight peak of cytochrome aa3 is observable in this strain, whereas no cytochrome $c$ oxidase activity is detectable (data not shown). All these observations suggest that the assembly of Cox $1 p$ through Cox $4 p$ follows a sequential mode as schematized in Fig. 5. The first step could be the association of Cox $2 p$ with Cox $1 p$, then Cox $4 p$ would associate with Cox $1 p$, and finally Cox $3 p$ would stabilize the three other subunits. We will test this model by immunoprecipitation experiments. Also further experiments on other mutants altered in the seven remaining subunits will be necessary to better understand the sequence of assembly of the cytochrome $c$ oxidase complex into the mitochondrial membranes.

Acknowledgements This work was supported by a European Community Stimulation Contract (CT90-0476) C. L. thanks Drs. M. Gervais, J. Daniel and M. Claisse for stimulating discussions. We also thank D. Menay for the synthesis of oligonucleotides. We are grateful to Drs. G. Dujardin, O. Groudinsky and to Dr. C. J. Herbert for critical reading of the manuscript and to C. J. H. for looking over the English.

\section{References}

Baranowska H, Szcesniak B, Ejchart A, Kruszewska A, Claisse M (1983) Recombinational analysis of oxi2 mutants and preliminary analysis of their translation products in $S$. cerevisiae. Curr Genet 7:225-233

Bonitz S, Corruzi G, Thalenfeld B, Tzagoloff A, Macino G (1980) Assembly of the mitochondrial membrane system - structure and nucleotide sequence of the gene coding for subunit I of yeast cytochrome oxidase. J Biol Chem 255: 11927-11941

Capaldi RA (1990) Structure and assembly of cytochrome $c$ oxidase. Arch Biochem Biophys 280:252-262

Carignani G, Netter P, Bergantino E, Robineau S (1986) Expression of the mitochondrial split gene coding for cytochrome oxidase subunit I in S. cerevisiae: RNA splicing pathway. Curr Genet 11:55-63

Claisse M, Pere-Aubert G, Clavilier L, Slonimski PP (1970) Méthode d'estimation de la concentration des cytochromes dans les cellules entières de levure. Eur J Biochem 16:430-438

Claisse ML, Slonimski PP, Johnson J, Mahler HR (1980) Mutations within an intron and its flanking sites: patterns of novel polypeptides generated by mutants in one segment of the cob-box region of yeast mitochondrial DNA. Mol Gen Genet 177:375-387

Dujardin G, Pajot P, Groudinsky O, Slonimski PP (1980) Long-range control circuits within mitochondria and between nucleus and mitochondria. I. Methodology and Phenomenology of Suppressors. Mol Gen Genet 179:469-482
Dujardin G (1983) Thèse de Doctorat d'Etat. Université Paris 6

Geier BM, Schagger H, Ortwein C, Link TA, Hagen WR, Brandt U (1995) Kinetic properties and ligand binding of the 11-subunit cytochrome $c$ oxidase from Saccharomyces cerevisiae isolated with a novel large-scale purification method. Eur J Biochem 227: 296-302

Glerum DM, Tzagoloff A (1997) Sub-mitochondrial distributions and stabilities of subunits 4, 5 and 6 of yeast cytochrome oxidase in assembly defective mutants. FEBS Lett 412:410-414

Groudinsky O, Dujardin G, Slonimski PP (1981) Long-range control circuits within mitochondria and between nucleus and mitochondria. II. Genetic and biochemical analyses of suppressors which selectively alleviate the mitochondrial intron mutations. Mol Gen Genet 184:493-503

Hensgens LAM, Bonen L, de Haan M, Horst G, Grivell LA (1983) Two intron sequences in the yeast mitochondrial COX I gene: homology among URF-containing introns and strain-dependent variation in flanking exons. Cell 32:379-389

Iwata S, Ostermeier C, Ludwig B, Michel H (1995) Structure at 2.8 A resolution of cytochrome $c$ oxidase from Paracoccus denitrificans. Nature 376:660-669

Kotylak Z, Slonimski PP (1977) Mitochondrial mutants isolated by a new screening method based upon the use of the nuclear mutation op1. In: Bandlow W, Schweyen RJ, Wolf K, Kaudewitz F (eds) Mitochondria (1977) Genetics and biogenesis of mitochondria. de Gruyter, Berlin New York, pp 83-89

Kruszewska A, Szcesniak B, Claisse M (1980) Recombinational analysis of OXI1 and preliminary analysis of their translation products in S. cerevisiae. Curr Genet 2:45-51

Laemmli UK (1970) Cleavage of structural proteins during the assembly of the head of bacteriophage T4. Nature 227: 680-685

Langer T, Neupert W (1996) Regulated protein degradation in mitochondria. Experientia 52:1069-1076

LaMarche AEP, Abate MI, Chan SHP, Trumpower BL (1992) Isolation and characterization of $C O X 12$, the nuclear gene for a previously unrecognized subunit of $S$. cerevisiae cytochrome $c$ oxidase. J Biol Chem 267: 22473-22480

Lemarre P, Robineau S, Colson A-M, Netter P (1994) Sequence analysis of three deficient mutants of cytochrome oxidase subunit I of Saccharomyces cerevisiae and their revertants. Curr Genet 26:546-552

Lemesle-Meunier D, Brivet-Chevillotte P, di Rago J-P, Slonimski PP, Bruel C, Tron T, Forget N (1993) Cytochrome $b$-deficient mutants of the ubiquinol-cytochrome $c$ oxidoreductase in Saccharomyces cerevisiae. Consequence for the functional and structural characteristics of the complex. J Biol Chem 268: $15626-15632$

Nakai T, Mera Y, Yasuhara T, Ohashi A (1994) Divalent metal iondependent mitochondrial degradation of unassembled subunits 2 and 3 of cytochrome $c$ oxidase. J Biochem 116:752-758

Netter P, Carignani G, Jacq C, Groudinsky O, Clavilier L, Slonimski PP (1982) The cytochrome oxidase subunit I split gene in $S$. cerevisiae: genetic and physical studies of the mtDNA segment encompassing the 'cytochrome $b$-homologous' intron. Mol Gen Genet 188:51-59

Netter P, Robineau S, Lemaire C (1995) Mutations in the mitochondrial split gene $C O X I$ are preferentially located in exons: a mapping study of 172 mutants. Mol Gen Genet 246: 445-454

Ortwein C, Link TA, Meunier B, Colson-Corbisier A-M, Rich PR, Brandt U (1997) Structural and functional analysis of deficient mutants in subunit I of cytochrome $c$ oxidase from Saccharomyces cerevisiae. Biochim Biophys Acta 1321:79-92

Oudshoorn P, Van Steeg H, Swinkels BW, Schoppink P, Grivell LA (1987) Subunit II of yeast QH2: cytochrome-c oxidoreductase. Nucleotide sequence of the gene and features of the protein. Eur J Biochem 163:97-103

Pajot P, Wambier-Kluppel ML, Kotylak Z, Slonimski PP (1976) Genetics and biogenesis of chloroplasts and mitochondria. Elsevier North Holland Biomedical Press, Amsterdam, pp 443-451

Poyton RO, Mc Ewen JE (1996) Cross-talk between nuclear and mitochondrial genomes. Annu Rev Biochem 65:563-607 
Rubin MS, Tzagoloff A (1973) Assembly of the mitochondrial membrane system. X. Mitochondrial synthesis of three of the subunit proteins of yeast cytochrome oxidase. J Biol Chem 249:42694274

Sanger F, Nicklen S, Coulson AR (1977) DNA sequencing with chain-terminating inhibitors. Proc Natl Acad Sci USA 74:54635467

Suzuki CK, Rep M, van Dijl JM, Suda K, Grivell LA, Schatz G (1997) ATP-dependent proteases that also chaperone protein biogenesis. Trends Biochem Sci 22:118-123

Taanman JW, Capaldi RA (1993) Subunit VIa of yeast cytochrome $c$ oxidase is not necessary for assembly of the enzyme complex but modulates the enzyme activity. Isolation and characterization of the nuclear-coded gene. J Biol Chem 268: 18754-18761

Taanman J-W, Burton MD, Marusich MF, Kennaway NG, Capaldi RA (1996) Subunit-specific monoclonal antibodies show different steady state levels of various cytochrome- $c$ oxidase subunits in chronic progressive external ophthalmoplegia. Biochim Biophys Acta 1315:199-207
Towbin H, Staehelin T, Gordon J (1979) Electrophoretic transfer of proteins from polyacrylamide gels to nitrocellulose sheets: procedure and applications. Proc Natl Acad Sci USA 76:4350-4354

Tron T, Lemesle-Meunier D (1990) Two substitutions at the same position in the mitochondrial cytochrome $b$ gene of $S$. cerevisiae induce a mitochondrial myxothiazol resistance and impair the respiratory growth of the mutated strains albeit maintaining a good electron transfer activity. Curr Genet 18:413-419

Tsukihara T, Aoyama H, Yamashita E, Tomizaki T, Yamaguchi H, Shinzawa-Itoh K, Nakashima R, Yaono R, Yoshikawa S (1995) Structures of metal sites of oxidized bovine heart cytochrome $c$ oxidase at 2.8A. Science 269:1069-1074

Tsukihara T, Aoyama H, Yamashita E, Tomizaki T, Yamaguchi H, Shinzawa-Itoh K, Nakashima R, Yaono R, Yoshikawa S (1996) The whole structure of the 13-subunit oxidized cytochrome $c$ oxidase at 2.8A. Science 272:1136-1144 